\title{
The Significance of Electroencephalography in the Follow-up of Patients with Cerebral Venous Thrombosis?
} Serebral Venöz Trombozlu Hastaların Takibinde Elektroensefalografinin Önemi

Keywords: Cerebral venous thrombosis, intracranial pressure, electroencephalography, epileptic seizures, pathophysiology

Anahtar Kelimeler: Serebral venöz tromboz, intrakraniyal basınç, elektroensefalografi, epileptik nöbet, patofizyoloji

\section{Dear Editor,}

I read the article by Gemici (1) with great interest, in which the author illustrated an interesting patient with cerebral venous thrombosis (CVT) in whom serial electroencephalography (EEG) showed resolution of bilateral frontal intermittent rhythmic delta activity (FIRDA) in accordance with the clinical recovery in the follow-up. In the conclusion of the study, the author suggested that EEG could be used as a noninvasive monitor in the followup of such patients with CVT when findings related to structural abnormalities such as FIRDA were found.

I appreciate the author for presenting this interesting case and drawing attention to the interesting aspects of this clinical situation. However, I would like to comment on the article for a better understanding of the report and present some additional perspectives. First, I think that the significance of FIRDA in EEG might have been further discussed in the report. In the referred article, Threlkeld et al. (2) also reported continuous frontally predominant rhythmic delta activity on continuous EEG monitoring, which had become intermittent within minutes of administering mannitol. Remarkably, on anticoagulation therapy and hyperosmolar therapy in the following 48-hour period, EEG normalized alongside improving mental status revealing a good correlation between EEG and the clinical findings of CVT. In early reports, FIRDA was associated with deep midline lesions, and a relationship with increased intracranial pressure (ICP) was hypothesized (3). However, as far as I know, this report of
Gemici (1) with the previous report by Threlkeld et al. (2) are the only illustrations mentioning the resolution of FIRDA activity with the recovery of ICP, which surely present a stronger relationship between FIRDA and ICP in terms of causation. I think that the significance of FIRDA and its use in the followup the patient should surely be investigated in future, prospective studies including larger numbers of patients with increased ICP. Remarkably, examining this relationship separately in patients with distinct etiologies of increased ICP (e.g. pseudotumor cerebri, CVT, hypertensive hydrocephalus, traumatic brain edema) may provide critical perspectives regarding the underlying pathophysiology of FIRDA. The results of these studies may also provide substantial contributions regarding the unknown aspects of these diseases and the pathophysiologic differences. For instance, an interesting discussion may be that why seizure after CVT is a common presentation, whereas its occurrence is rarer in other etiologies of increased ICP? It has been reported that epileptic seizures following CVT can be seen at rates ranging from $40 \%$ to $64 \%(4,5,6)$. The subgroup of patients with supratentorial lesions or focal neurologic deficit is particularly reported to be at increased risk for developing seizures (7). On the other hand, it is also known that seizures are much more encountered in patients with CVT without parenchymal lesions and focal neurologic deficits in comparison with patients with pseudotumor cerebri [idiopathic intracranial hypertension (IIH)], a distinct etiology of increased ICP. Parenchymal lesions, particularly those including the motor cortex and sensory cortex, have been emphasized as

\footnotetext{
Address for Correspondence/Yazışma Adresi: Halil Önder MD, Yozgat City Hospital, Clinic of Neurology, Yozgat, Turkey Phone: +90 3544442066 E-mail: halilnder@yahoo.com ORCID: orcid.org/0000-0002-1823-2278

Received/Geliş Tarihi: 15.04.2019 Accepted/Kabul Tarihi: 04.10.2019

${ }^{\circ}$ Copyright 2020 by Turkish Neurological Society

Turkish Journal of Neurology published by Galenos Publishing House.
} 
risk factors for the development of epileptic seizures in CVT (8). In addition, occlusion of the superior sagittal sinus and cortical veins, which drain venous blood from the upper convexity of the brain, including the motor and sensory cortices, also increase the risk of seizures, suggesting disturbed venous malfunction of these regions, which might not result in neuroimaging evidence on magnetic resonance imaging in some patients (8). However, at this point, the issue of whether changes in ICP can solely evoke seizures remains controversial. Besides, there are also some other differing features of CVT from IIH such as decreased intracranial cerebrospinal fluid (CSF) volume, albeit with increased ICP, which was hypothesized to be responsible for the orthostatic headache in patients with CVT (9). Taken together, I think that EEG data may provide crucial perspectives for our understanding of the pathophysiology of epileptic seizures in CVT and unknown CSF dynamics in CVT (besides its potential significance in monitoring ICP). The significance of FIRDA and its possible predictive value in seizure development may be other interesting topics for deliberations in future studies.

A major limitation of this report may be that the detailed laboratory data of the patient were not included in the report. A recent study suggested that FIRDA most frequently occurred with diffuse brain injury, along with mild-to-moderate metabolic impairment (10). Strikingly, half of the patients were reported to have renal failure (10). At this point, I wonder if the author might indicate that a metabolic disturbance was present in the patient, which would provide a clearer understanding of the relevance of FIRDA.

\section{Ethics}

Informed Consent: It was not taken.
Peer-review: Externally peer-reviewed.

Financial Disclosure: The authors declared that this study received no financial support.

\section{References}

1. Gemici Yİ. Cerebral venous thrombosis can be followed by electroencephalography: accompanied by a case discussion. Turk J Neurol 2019;25:47-49.

2. Threlkeld ZD, Kottapally M, Aysenne A, Kon N. Continuous qualitative electroencephalography as a noninvasive neuromonitor. Neurohospitalist 2016;6:157-160.

3. Cordeau JP. Monorhythmic frontal delta activity in the human electroencephalogram: a study of 100 cases. Electroencephalogr Clin Neurophysiol 1959;11:733-746.

4. Bharatkumar VP, Rudreshkumar KJ, Nagaraja D, Christopher R. Plasma S-adenosylhomocysteine: a potential risk marker for cerebral venous thrombosis. Clin Chim Acta 2016;458:44-48.

5. Kalita J, Chandra S, Misra UK. Significance of seizure in cerebral venous sinus thrombosis. Seizure 2012;21:639-642.

6. Saposnik G, Barinagarrementeria F, Brown RD Jr, et al. Diagnosis and management of cerebral venous thrombosis: A statement for healthcare professionals from the American Heart Association/American Stroke Association. Stroke 2011;42:1158-1192.

7. Mehvari Habibabadi J, Saadatnia M, Tabrizi N. Seizure in cerebral venous and sinus thrombosis. Epilepsia Open 2018;3:316-322.

8. Ferro JM, Canhao P, Bousser MG, Stam J, Barinagarrementeria F; ISCVT Investigators. Early seizures in cerebral vein and dural sinus thrombosis: risk factors and role of antiepileptics. Stroke 2008;39:1152-1158.

9. Kim JB, Kwon DY, Park MH, Kim BJ, Park KW. Paradoxical presentation of orthostatic headache associated with increased intracranial pressure in patients with cerebral venous thrombosis. Ann Indian Acad Neurol 2013;16:85-87.

10. Watemberg N, Alehan F, Dabby R, Lerman-Sagie T, Pavot P, Towne A. Clinical and radiologic correlates of frontal intermittent rhythmic delta activity. J Clin Neurophysiol 2002;19:535-539. 